\title{
TECHNOLOGY OF SOCIO-PEDAGOGICAL SUPPORT ORGANIZING FOR THE FORMATION OF A RESPONSIBLE CIVIC POSITION IN GENERAL EDUCATION INSTITUTIONS
}

\section{Tetyana Kunytsia ${ }^{1}$}

DOI: https://doi.org/10.30525/978-9934-26-002-5-6

In Ukraine among the educational areas patriotic and civic education is determined as the most relevant, due to the fact it meets both the urgent requirements and challenges of our time, and lay the foundations for the formation of consciousness of current and future generations, who will consider the state as the key to their own personal development, based on the ideas of humanism, social well-being, democracy, freedom, tolerance, balance, responsibility, healthy lifestyle, readiness for change.

Children from internally displaced families need the greatest attention to civic education and the formation of a responsible civic position due to a number of factors. In particular, due to the negative experience and contradictions between the state's declared guarantees of security rights and the situation in the Donetsk and Luhansk regions and the Autonomous Republic of Crimea. The formation of knowledge about the civil rights of a person (child), the importance of responsible participation in duties, the possibility of real participation in democracy according to age opportunities, the development of critical thinking, the assimilation of media literacy skills are important components of a responsible civic position of a teenager.

Socio-pedagogical support for the formation of a responsible civic position allows the child to realize themselves more fully by stimulating appropriate and successful behavior, promotes socialization and accumulation of sociosignificant experience.

Support does not involve overprotection of the accompanied person, but is aimed at stimulating his conscious, purposeful activity.

Work on organizing socio-pedagogical support for the responsible civic position of children from of internally displaced families is carried out with such subjects of the educational process - children and the children's team and teachers.

Based on the algorithm of socio-pedagogical support implementation at the diagnostic stage, the following parameters are determined:

- value orientations;

\footnotetext{
${ }^{1}$ Institute of Education Problems of the National Academy of Pedagogical Sciences of Ukraine, Ukraine
} 
- social roles that displaced children identify with;

- the level of formation of a responsible civic position;

- the degree of teachers readiness to provide socio-pedagogical support.

For this purpose, standardized and author's tests, tests and questionnaires can be used, in particular, «Value orientations» by M. Rokych, the test «Who am I?» by M. Kun. Regarding the author's methods, a questionnaire «Civil position of pupils» was developed, the purpose of which was to determine how children understand the concept of civic position in general and responsible position in particular, what they consider as its components, and how they manifest it in everyday life.

Working with teachers, it is important to determine, firstly, their understanding of the concept of citizenship, and secondly, the degree of their readiness to provide socio-pedagogical support. It is worth paying attention to the fact that today not all educational institutions have a specialist in social pedagogy, so practical psychologists and classroom teachers can be also involved in organizing socio-pedagogical support.

At the analytical stage, the obtained empirical information is processed. It should be noted that a significant part of respondents (both children and teachers) identify a responsible civic position with patriotism.

According to I. D. Bekh and K. I. Chornaya "patriotism is love for the Motherland, one's people, concern for its good, promoting the formation and establishment of Ukraine as a sovereign, legal, democratic, social state, readiness to defend its independence, serve and defend it, share one's fate with its fate» $[1$, p. 16$]$.

Responsible citizenship is an integrative quality of the individual, which is characterized by a high degree of citizenship and legal culture, manifested in a combination of civic consciousness, the desire for positive self-realization, moral and volitional qualities and feelings, as well as civil actions and behavior (author's definition).

Criteria and indicators for the formation of a responsible civic position:

$\checkmark$ Cognitive-valuable:

- knowledge of citizenship;

- attitude to the motherland;

- legal culture;

$\checkmark \quad$ Emotional and motivational:

- interest in the socio-political life of a school, city, or country;

- attitude to yourself as a citizen;

- the need for positive self-realization;

$\checkmark \quad$ Behavioral and activity-based:

- compliance with social and legal norms of behavior;

- participation in public activities of various levels; 
- independence and initiative in the implementation of socially significant activities.

At the strategic stage, the goal is determined: to form a responsible civic position in children from internally displaced families in the conditions of a general education institution; tasks: to develop programs for individual support of displaced persons and group forms of work; to prepare teachers for the implementation of socio-pedagogical support for the formation of a responsible civic position; socio-pedagogical conditions: a combination of individual and collective forms of work with displaced children; taking into account the age, social, psychological characteristics of displaced children; establishing interaction between all subjects of the educational process.

Design and advisory stages. Socio-pedagogical support consists in helping the child to form an attitude towards himself as a citizen of the state, in positive self-realization in this capacity, promoting independence and initiative in the implementation of socially significant activities. With team it is implemented through the organization of practical socially significant activities, assistance to students in showing initiative, creativity in achieving individual and collective goals, the formation of skills of constructive interaction in small groups, the acquisition of experience in responsible behavior in specific situations; the assimilation and implementation of civil rights and obligations. With teachers - through improving the level of pedagogical and legal culture, training and mastering the technology of providing socio-pedagogical support.

In an individual support program, it is advisable to use the method of introspection in the form of creating a student profile «One page profile» [3], for the development of analytical skills - the «Insert» technique (the authors of the technique are scientists D. Vaughan and T. Estes. Later, the technique was modified by C. Temple, K. Meridith and D. Still, who suggested using «insert» in the technology of critical thinking), in order to develop skills in predicting goals and ways to achieve them - writing an essay «Me - in 5 years». In parallel with individual work, group work should also take place. This is a series of classes with elements of training that address civil rights and obligations; participation of young people in socially significant activities; problems of migration and migrants. In particular, the materials Compass: Manual for Human Rights Education with Young people can be used [2] part of the classes should be devoted to the development of critical thinking and media literacy of the growing personality.

Thus, in order to achieve positive results, socio-pedagogical support for the formation of a responsible civic position should be implemented in compliance with a clear algorithm, both through individual and collective forms of work. 


\section{References:}

1. Bekh, I. D., \& Chornaya, K. I. (2008). Nacionaljna ideja $v$ stanovlenni ghromadjanyna-patriota Ukrajiny: (proghramno-vykhovnyj kontekst) [National idea in becoming a citizen-patriot of Ukraine: (program-educational context)]. Kyiv: IPV APN Ukrainy. (in Ukrainian)

2. Compass: Manual for Human Rights Education with Young people (2010). Retrieved from: https://www.coe.int/en/web/compass (accessed 15 June 2020).

3. One-page profile templates. Retrieved from: http://helensandersonassociates.co.uk/ person-centred-practice/one-page-profiles/one-page-profile-templates/ (accessed 08 September 2020).

\section{FORMATION OF INFORMATION AND DIGITAL CULTURE OF FUTURE SPECIALISTS OF PHYSICAL CULTURE AND SPORTS BY MEANS OF INFORMATION AND EDUCATIONAL ENVIRONMENT OF HIGHER EDUCATION INSTITUTION}

\section{Serhiy Lazorenko ${ }^{1}$}

\section{DOI: https://doi.org/10.30525/978-9934-26-002-5-7}

The latest trends in society require the development of the education system, in particular the training of future specialists in physical culture and sports (FK\&S), on the basis of information technology, the creation and operation of appropriate high-tech and high-quality information and educational environment. Its importance has been growing recently and qualitatively influences the process of formation and development of information and communication culture of future specialists of FC\&S. The global educational space includes a single space of the education system, which includes the information and educational environment of the free educational system, which is a set of informational, technical, educational and methodological support with established links and connects the subjects of the educational process.

The information and educational environment (I\&EE) should be perceived as the integration of the electronic campus of the educational institution, educational process management tools, pedagogical technologies designed to form an intellectually developed creative personality of FK\&S specialist, who has the necessary level of information and communication culture,

\footnotetext{
${ }^{1}$ Makarenko Sumy State Pedagogical University, Ukraine
} 